\title{
Virulence of Plant Pathogenic Bacteria Attenuated by Degradation of Fatty Acid Cell-to-Cell Signaling Factors
}

\author{
Karyn L. Newman, Subhadeep Chatterjee, Kimberly A. Ho, and Steven E. Lindow \\ Department of Plant and Microbial Biology, University of California, Berkeley, CA 94720, U.S.A.
}

Submitted 2 June 2007. Accepted 7 November 2007.

Diffusible signal factor (DSF) is a fatty acid signal molecule involved in regulation of virulence in several Xanthomonas species as well as Xylella fastidiosa. In this study, we identified a variety of bacteria that could disrupt DSF-mediated induction of virulence factors in Xanthomonas campestris pv. campestris. While many bacteria had the ability to degrade DSF, several bacterial strains belonging to genera Bacillus, Paenibacillus, Microbacterium, Staphylococcus, and Pseudomonas were identified that were capable of particularly rapid degradation of DSF. The molecular determinants for rapid degradation of DSF in Pseudomonas spp. strain $G$ were elucidated. Random transposon mutants of strain $G$ lacking the ability to degrade DSF were isolated. Cloning and characterization of disrupted genes in these strains revealed that $\operatorname{car} A B$, required for the synthesis of carbamoylphosphate, a precursor for pyrimidine and arginine biosynthesis is required for rapid degradation of DSF in strain G. Complementation of $\operatorname{carAB}$ mutants restored both pyrimidine prototrophy and DSF degradation ability of the strain G mutant. An Escherichia coli strain harboring carAB of Pseudomonas spp. strain G degrades DSF more rapidly than the parental strain, and overexpression of $c a r A B$ in trans increased the ability of Pseudomonas spp. strain $G$ to degrade as compared with the parental strain. Coinoculation of $X$. campestris pv. campestris with DSF-degrading bacteria into mustard and cabbage leaves reduced disease severity up to twofold compared with plants inoculated only with the pathogen. Likewise, disease incidence and severity in grape stems coinoculated with Xylella fastidiosa and DSF-degrading strains were significantly reduced compared with plants inoculated with the pathogen alone. Coinoculation of grape plants with a carAB mutant of Pseudomonas spp. strain G complemented with $\operatorname{car} A B$ in trans reduced disease severity as well or better than the parental strain. These results indicate that overexpression of $\operatorname{car} A B$ in other endophytes could be a useful strategy of biocontrol for the control of diseases caused by plant pathogens that produce DSF.

Additional keywords: AHL, EPS, quorum-quenching.

Numerous species of bacteria coordinate gene expression in a cell density-dependent fashion by production of small molecules, such as $N$-acyl homoserine lactones (AHL), small pep-

\section{K. L. Newman and S. Chatterjee contributed equally to this work.}

Corresponding author: S. Lindow; E-mail: icelab@berkeley.edu.

The nucleotide sequence of $c a r A B$ is available in the GenBank database under accession number bankit1018805 (EU162747). tides, butyrolactone derivatives, or fatty acids (Bassler 2002; Wang et al. 2004; Whitehead et al. 2001). These signals, which increase in concentration with cell density, typically are involved in the coordination of the expression of genes involved in exploitation of a host organism. The virulence of many pathogens is greatly reduced when the ability to produce signaling compounds is disrupted by mutation (Kievit and Iglewski 2000; vonBodman et al. 2003). The coordinate expression of virulence traits in a cell density-dependent fashion presumably occurs because cells would not benefit from expression of virulence traits when in low numbers in a host. The expression of such traits by solitary cells would be futile and a deleterious waste of metabolic resources. Conversely, when part of a group, expression of virulence traits would be mutually beneficial, and hence, cells express such traits only when in high numbers. Also, host responses to infection often are triggered only upon detection of virulence traits or their effect on the plant, such as by release of degraded host material (Beliěn et al. 2006; Jha et al. 2005). Delay in expression of virulence factors until cell densities increase to a large size would allow pathogens to avoid host responses until a time when they could cause injury to a host. Such phenomenon are often referred to as quorum sensing, in which bacterial traits are expressed primarily only when a population has exceeded a minimum threshold density.

The plant pathogen Xanthomonas campestris pv. campestris, which causes black rot in cruciferous crops such as cabbage and broccoli, expresses tissue-macerating pathogenicity genes upon the accumulation of a diffusible signal factor (DSF). This cell-to-cell communication system in which RpfF functions as the DSF synthase (Barber et al. 1997; Crossman et al. 2001) is required for virulence. DSF from $X$. campestris pv. campestris has been characterized as cis-11-methyl-2-dodecenoic acid (Wang et al. 2004). Mutations in $r p f F$ reduce virulence because pathogenicity traits such as cellulases are no longer expressed in $r p f F$ mutants (Barber et al. 1997). Similarly, rpfF mutations in X. oryzae pv. oryzae, which causes bacterial leaf blight in rice, also reduce virulence and iron uptake (Chatterjee and Sonti 2002). The rpfF homolog of Xylella fastidiosa, which causes Pierce's disease of grape, citrus variegated chlorosis, and almond leaf scorch, synthesizes a cell-to-cell signal similar to but apparently slightly different from that of $X$. campestris pv. campestris (Colnaghi et al. 2007; Newman et al. 2004; Scarpari et al. 2003). Unlike $X$. campestris pv. campestris and $X$. oryzae pv. oryzae, Xylella fastidiosa requires insect vectors for spread from plant to plant. Intriguingly, Xylella fastidiosa rpfF mutants exhibit increased virulence to plants but are unable to form a biofilm within insect vectors that acquire this mutant and, thus, cannot be spread from plant to plant by their insect vectors (Newman et al. 2004). Thus, as in Xanthomonas species, DSF perception also appears to play an important role in the biology of Xylella fastidiosa. 
There has been growing interest in the evaluation of pathogen confusion as a means of disease control. Such a phenomenon is also referred to as quorum-quenching, in that traits that would normally be expressed when cell densities are high are suppressed by altering the abundance of cell-to-cell signaling compounds (Dong and Zhang 2005; Dong et al. 2000, 2001; Gonzalez and Keshavan 2006). The best understanding of such signal interference is in bacterial species that communicate via AHL. Several organisms have been identified that can degrade AHL signals via AHL acylase or AHL lactonase activities (Dong and Zhang 2005; Gonzalez and Keshavan 2006). The coinoculation of such strains with AHL-producing plant pathogens reduced disease severity (Cho et al. 2007; Cui and Harling 2005; Zhang 2003). Likewise, expression of an AHL lactonase in tobacco plants also dramatically reduced the severity of disease caused by Erwinia carotovora (Zhang 2003). Some plant species in which AHL production has been introduced exhibit resistance to diseases caused by AHL-producing bacteria (Mäe et al. 2001; Quiñones et al. 2005). Together, these studies demonstrate that interference of signaling leading to disease control can be achieved by either inhibiting signaling or by providing excess signal.

Pathogen confusion has not been investigated as a means to alter the virulence of DSF-producing bacteria. Several genera of phytopathogenic bacteria produce DSF (Barber et al. 1997; Chatterjee and Sonti 2002; Colnaghi et al. 2007; Newman et al. 2004; Wang et al. 2004). AHL lactonase-producing organisms are not able to degrade DSF produced by either Xylella fastidiosa or X. campestris pv. campestris (K. L. Newman and S. E. Lindow, unpublished), which has a very different chemical structure from that of AHL (Wang et al. 2004). In this study, we identified bacteria that could disrupt DSF-mediated signaling

Table 1. Strains and plasmids

\begin{tabular}{|c|c|c|}
\hline Strain or plasmid & Description $^{a}$ & $\begin{array}{l}\text { Source or } \\
\text { reference }\end{array}$ \\
\hline \multicolumn{3}{|c|}{ Xanthomonas campestris pv. campestris strains } \\
\hline 8004 & Wild type $\left(\right.$ Rif $\left.^{r}\right)$ & Turner et al 1984 \\
\hline 8523 & $r p f F:: \operatorname{Tn} 51 \mathrm{lac}\left(\mathrm{Rif}^{\mathrm{r}}, \mathrm{Km}^{\mathrm{r}}\right)$ & Tang et al 1991 \\
\hline 8004 (pKLN 55) & $\mathrm{Rif}^{\mathrm{r}}, \mathrm{Sp}^{\mathrm{r}}, \mathrm{St}^{\mathrm{r}}$ & This study \\
\hline \multicolumn{3}{|c|}{ Xylella fastidiosa strains } \\
\hline Temecula & Wild type, Pierce's disease & ATCC 700964 \\
\hline STL & Wild type, Pierce's disease & Lab collection \\
\hline \multicolumn{3}{|l|}{ Plasmids } \\
\hline pKLN 55 & $\begin{array}{l}\text { engXCA promoter-gfp, } \mathrm{Sp}^{\mathrm{r}}, \mathrm{St}^{\mathrm{r}}, \\
\mathrm{mob}^{+}\end{array}$ & Newman et al 2004 \\
\hline \multirow{2}{*}{$\begin{array}{l}\text { pVSP61 } \\
\text { pSC4 }\end{array}$} & $\mathrm{Sp}^{\mathrm{r}}$ & Whalen, et al. 1991 \\
\hline & $\begin{array}{l}\text { carAB genes from strain } \mathrm{G} \text { in } \\
\text { pVSP61 }\end{array}$ & This study \\
\hline
\end{tabular}

in both X. campestris pv. campestris and Xylella fastidiosa, explored the mechanism by which cell signaling was blocked by these strains, and determined the molecular determinants required by Pseudomonas spp. strain G for rapid modification of DSF. We then tested whether interfering with DSF-mediated cell-to-cell signaling by enzymatic modification of the DSF signal molecule could attenuate virulence of DSF-producing plant-pathogenic bacteria. We focused our study on the wellcharacterized DSF-producing pathogens $X$. campestris pv. campestris and Xylella fastidiosa, which cause dissimilar diseases on a variety of plant species but which have in common the regulation of virulence via the production of DSF.

\section{RESULTS}

\section{Identification of DSF-inhibiting bacteria.}

Bacteria recovered from field-grown plants infected with DSF-producing plant pathogens were screened for the ability to block DSF-mediated induction of an eng:gfp (endoglucanase green fluorescent protein) gene fusion (pKLN55; Newman et al. 2004) in the $X$. campestris pv. campestris 8004 , which produces its own DSF, in a plate assay (Table 1). A large number of bacteria with different cultural appearances were isolated from $X$. fastdiosa-infected grapevines (590 isolates), X. campestris pv. campestris-infected broccoli leaves (99 isolates) or cabbage leaves (209 isolates), or X. campestris pv. vesicatoriainfected tomato leaves (141 isolates). Strains were spotted on plates, oversprayed with X. campestris pv. campestris 8004 (pKLN55) and were screened for the ability to inhibit GFP expression by the DSF reporter in the vicinity of test colonies. A total of nine DSF-inhibiting bacteria were identified; four strains were isolated from grapevine, three from cabbage, one from broccoli, and one from tomato. A survey of the $16 \mathrm{~S}$ ribosomal RNA gene sequence from the DSF-inhibiting isolates revealed that the DSF-inhibiting strains included members of the gram-positive genera Bacillus, Paenibacillus, Microbacterium, and Staphylococcus, as well as members of the gramnegative genus Pseudomonas (Table 2).

DSF-inhibiting strains were further analyzed to determine whether their disruption of DSF-mediated signaling was due to modification or degradation of DSF or whether inhibition was occurring by an alternate mechanism. Cells were incubated with exogenous DSF in liquid culture, and DSF was subsequently recovered and quantified. Most strains were able to degrade or modify DSF to a form that was no longer detectable by the $X$. campestris pv. campestris biosensor, as indicated by a lack of recovery of the added DSF from cultures of those strains (Table 2). Importantly, boiling the cell extracts prior to incubation with DSF abolished the DSF degradation ability, indicating that enzymatic degradation may be involved in the DSF-interference phenomenon of these bacterial strains.

Table 2. Characteristics of diffusible signal factor (DSF)-interfering bacterial strains isolated from various plants and laboratory strains

\begin{tabular}{|c|c|c|c|c|c|}
\hline Strain name & Identity $^{\mathbf{a}}$ & $\%$ Identity $^{\mathrm{b}}$ & Origin & DSF degradation $^{c}$ & Mechanism of DSF inhibition \\
\hline A & Paenibacillus paduli & 96 & Grapevine & +++ & Unknown \\
\hline B & Paenibacillus paduli & 97 & Grapevine & +++ & Unknown \\
\hline $\mathrm{C}$ & Pseudomonas sp. Bsi20664 & 99 & Cabbage & +++ & Enzymatic degradation \\
\hline $\mathrm{D}$ & Staphylococcus pasteur & 99 & Grapevine & +++ & Unknown \\
\hline $\mathrm{E}$ & Bacillus cereus & 99 & Broccoli & +++ & Enzymatic degradation \\
\hline G & Pseudomonas sp. strainBsi20664 & 99 & Cabbage & +++ & Enzymatic degradation \\
\hline $\mathrm{H}$ & Pseudomonas jessenii Ps06 & 99 & Cabbage & +++ & Enzymatic degradation \\
\hline $\mathrm{J}$ & Pseudomonas sp. Fa2 & 99 & Tomato & +++ & Enzymatic degradation \\
\hline \multirow[t]{2}{*}{$\mathrm{L}$} & Staphylococcus sp. esl & 99 & Grapevine & ++ & Unknown \\
\hline & Escherichia coli (DH5 $\alpha)$ & & Lab collection & + & Unknown \\
\hline
\end{tabular}

\footnotetext{
${ }^{a}$ Identity of taxa with closest BLAST score to the sequence of the 16S RNA gene of test strain.

${ }^{\mathrm{b}}$ Percent identity of the 16S RNA gene in the RDB database to the closest match to test strain.

${ }^{\mathrm{c}}$ Semiquantitative estimates of DSF degradation ability based on plate inhibition assay.
} 
Our screen of environmental isolates suggested that DSF degradation is a relatively rare trait among the plant-associated bacteria that we isolated, because only a small percentage of strains were capable of inhibiting DSF signaling. However, when we used the in vitro DSF-degradation assay to explore mechanisms of disruption of signaling, we were surprised to find that, given long incubation times of $24 \mathrm{~h}$ or more, nearly all of the strains we tested from our lab stocks, including common Escherichia coli cloning hosts, also degraded DSF, although none of these strains produced a detectable "halo" indicative of rapid disruption of DSF signaling in our gfp-based plate diffusion assay (Table 2). We then sampled a selection of strains from our initial screen of plant-associated bacteria and found that five of the six randomly selected strains could modify or degrade DSF given long incubation periods in the in vitro assay. We interpret this to mean that DSF degradation is a common bacterial trait but that only a few strains are capable of rapid, efficient degradation sufficient to cause a halo in the gfp-based plate assay. The rate of degradation of DSF by different bacterial strains was determined in in vitro studies by measuring DSF remaining at various times after addition to cell suspensions. The rate of DSF degradation conferred by strain $\mathrm{G}$ was 2.7 -fold faster than that conferred by $E$. coli DH10B (Fig. 1). Thus, some bacterial strains, such as Pseudomonas spp. strain G, exhibit much greater DSF-degradation capabilities than most other bacteria.

\section{Characterization of genes required for DSF degradation.}

As the mechanism for DSF degradation in bacteria such as Pseudomonas spp. strain G was unknown, we utilized a strategy of random transposon mutagenesis to identify genes required for this process. Transposon Tn5-RL27 (kanamycinresistant; Larsen et al. 2002) was used to generate a random insertion library of strain $G$ that was then screened for mutants that were unable to confer formation of a halo of disrupted DSF signaling surrounding colonies oversprayed with the eng:gfp-containing $X$. campestris pv. campestris indicator strain as above. Three independent transposon insertion mutants (G741, G29101, G2951) that are unable to disrupt DSF

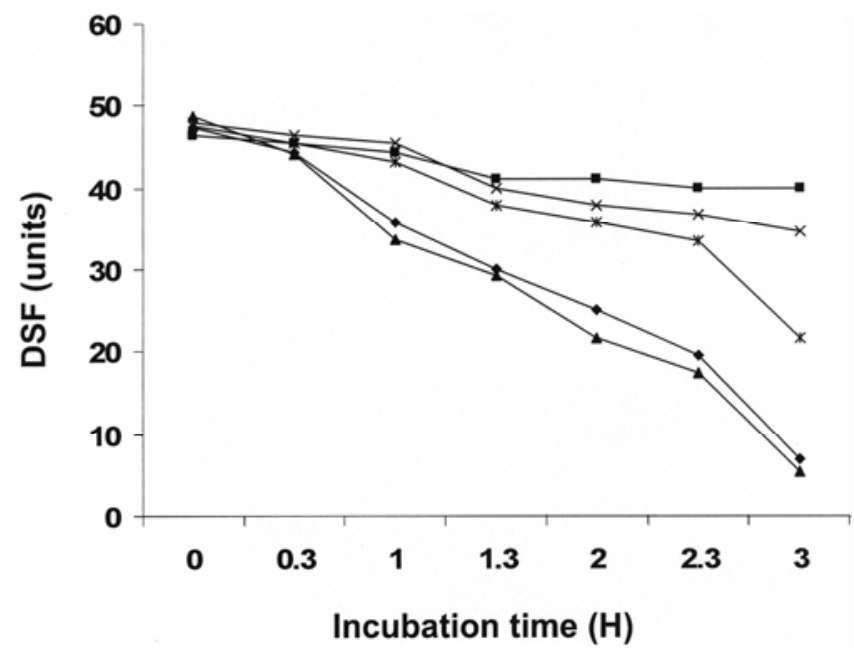

Fig. 1. Kinetics of diffusible signal factor (DSF) degradation in bacterial strains differing in expression of CarAB. Cell suspensions of Pseudomonas spp. strain G (diamonds) or Pseudomonas spp. strain G CarAB mutant G741 (squares), mutant G741 complemented with plasmid pSC4 (triangles), Escherichia coli DH10B (pVSP61) (×), or E. coli DH10B (pSC4) (asterisks) were incubated with $50 \mu \mathrm{l}$ of DSF, which was subsequently extracted at various timepoints with ethyl acetate and were quantified with a Xanthomonas campestris pv. campestris eng:gfp biosensor. Each timepoint represents the average of four replicate samples for each treatment. Similar patterns of DSF degradation were also obtained in three independent experiments. signaling were identified. Cloning of the inserted transposon along with the flanking chromosomal DNA from mutants G741, G29101, and G2951 revealed that they each had an insertion in either $\operatorname{carA}$ or $\operatorname{carB}$ (Fig. 2). The transposon insertion in G741 and G2951 was located at a position corresponding to codons 457 and 658 of the $c a r B$ gene, which encodes an open reading frame (ORF) of 1,073 amino acids (Fig. 2). Transposon insertion G29101 was located at a position corresponding to codon 278 of the carA gene, which encodes an ORF of 378 amino acids (Fig. 2).

To isolate the wild-type $\operatorname{car} A B$ genes, the sequence of the chromosomal DNA flanking the transposon insertion was used to design primers that amplify the entire $\operatorname{car} A B$ operon from the strain. A 4.843-kb fragment containing $\operatorname{car} A B$ along with $112 \mathrm{bp}$ of upstream sequence (which contains the predicted promoter of the $c a r A B$ operon) was amplified from strain $G$ and was cloned in the broad-host range vector pVSP61 to produce pSC4 (Table 1). The 4.843-kb genomic region of the strain $\mathrm{G}$ was determined by primer walking. The $\operatorname{car} A B$ locus of Pseudomonas spp. strain G shows strong homology to $\operatorname{car} A B$ genes of other Pseudomonas strains. Nucleotide sequence analysis of the 4.843-kb region revealed highest $(96 \%)$ identity at the nucleotide level to the Pseudomonas fluorescence Pfo-1 genomic region encoding carA and $\operatorname{car} B$. Sequence analysis of $c a r A$ and $c a r B$ indicated that the genomic organization of $\operatorname{car} A B$ is also similar to that in other Pseudomonas strains such as Pseudomonas syringae pv. tomato DC3000 (Buell et al. 2003), Pseudomonas fluorescens Pf-5 (Paulsen et al. 2005), and Pseudomonas syringae pv. syringae B728a (Feil et at. 2005). Interestingly, in Pseudomonas aeruginosa PAO1, there is a conserved hypothetical protein (PA4757) located between $\operatorname{car} A$ and $c a r B$ in an operon formed by these genes (Kwon et al. 1994).

\section{Phenotypes of $\operatorname{car} A B$ mutants.}

carAB mutants of Pseudomonas spp. strain G are deficient in several traits. As expected of either a $\operatorname{car} A$ or a $\operatorname{car} B$ mutant, mutants G741, G29101, and G2951 are auxotrophic for arginine as well as pyrimidines (Fig. 3, left). In addition, these mutants are deficient in extracellular polysaccharide production when grown on King's B (KB; King et al.1954) medium compared with the wild-type strain (Fig. 3, right). Introduction of $\mathrm{pSC} 4$ harboring $c a r A B$ into each of the mutants restored both exopolysaccharide (EPS) production and prototrophy (Fig. 3, data shown only for G741). Supplementation of minimal media with pyrimidines and arginine $(200 \mu \mathrm{m}$ each) alleviated the growth deficiency as well as the EPS-deficiency phenotypes of G741, G29101, and G2951 (data not shown).

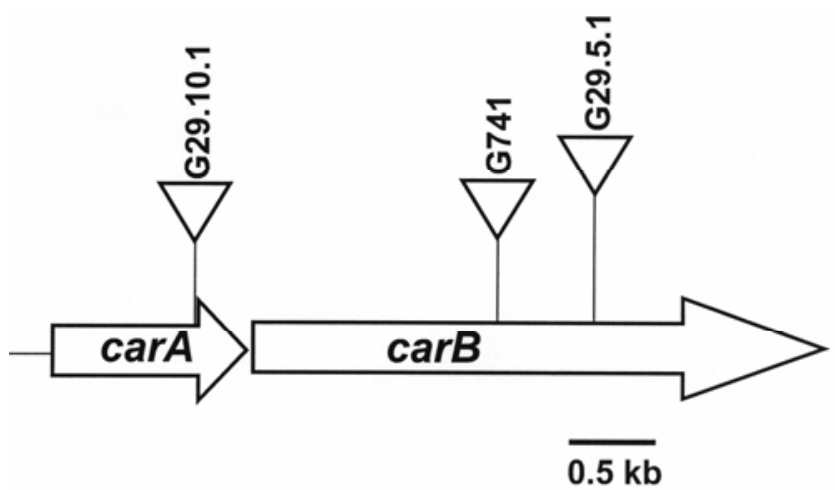

Fig. 2. Genomic organization of the carAB operon in Pseudomonas spp. strain G. The orientation of the direction transcription is shown with the arrow. Open triangles indicate the transposon insertion sites in mutants G741, G29101, and G2951. 


\section{DSF degradation kinetics.}

Quantitative differences in degradation of DSF among bacterial strains and the contribution of $\operatorname{car} A B$ to this process was documented by measuring the rates of DSF degradation in vitro (Fig. 1). To study the kinetics of DSF degradation, DSF was added to cell suspensions of test strains and the amount of DSF remaining at different timepoints was assessed using the DSF bioindicator $X$. campestris pv. campestris spp. strain 8523 (pKLN55) (Newman et al. 2004; Table 1). A relationship between known amounts of DSF added to wells in an agar assay plate (measured in microliters) and the diameter of a zone of DSF-mediated gfp fluorescence of the indicator strain that was unable to produce its own DSF enabled estimates to be made of the concentration of DSF remaining in test samples. Wildtype Pseudomonas spp. strain G degraded DSF at a rate about 2.7 times faster than that of E. coli DH10B (Fig. 1); the rate of DSF degradation in cultures of strain $G$ was about 13 DSF units per hour compared with 4.8 DSF units per hour for $E$. coli DH10B. In contrast, little DSF degradation was observed in a carB mutant (G741) of strain G (rate of DSF degradation 2.4 units/h) and this mutant degraded DSF much more slowly than even E. coli DH10B (Fig. 1). Introduction of pSC4 into mutant G741 restored the DSF degradation ability of the mutant to a level slightly greater than that of the wild-type strain $\mathrm{G}$ (13.99 DSF units per hour; Fig. 1). Likewise, introduction of carAB from Pseudomonas spp. strain G on pSC4 into E. coli DH10B greatly increased its ability to degrade DSF; the rate of DSF degradation in DH10B (pSC4) was 7.8 DSF units per hour compared with $4.8 \mathrm{DSF}$ units per hour in $E$. coli DH10B (Fig. 1).

Since $E$. coli harbors its own $\operatorname{car} A B$ homologs, we tested whether it was contributing to the intrinsic ability of $E$. coli to degrade DSF, albeit at a lower rate than bacteria such as Pseudomonas spp. strain G. Parental E. coli P4X exhibits a lower ability to degrade DSF (6.098 units/h; data not shown) than strain $\mathrm{G}$ although higher than $E$. coli DH10B. In contrast, a carA mutant of strain P4X (carA178; Mergeay et al. 1974) exhibited a greatly reduced ability to degrade DSF (3.98 units/h) as compared with the parental $E$. coli $\mathrm{P} 4 \mathrm{X}$. Thus carAB apparently contributes to the ability of most bacteria to slowly degrade DSF, but the carAB of some strains, such as Pseudomonas spp. strain G, encode superior capabilities for DSF degradation.

\section{Alteration of DSF characteristics by strain G.}

To further investigate the process of DSF degradation and modification by Pseudomonas spp. strain G, we examined the mobility of DSF extracted after treatment with cell-free extracts of different bacterial strains by thin-layer chromatography (TLC). DSF treated with cell extracts of Pseudomonas spp. strain $G$ appeared to be altered in mobility as compared with the native DSF extracted from $X$. campestris pv. campestris and added to the mixture (Fig. 4A and E). While there was much less gfp fluorescence conferred by the treated DSF compared with the control, the residual gfp fluorescence was associated with at least two altered forms of DSF detected by the $X$. campestris pv. campestris biosensor, one with higher and one with lower mobility than the native DSF (Fig. 4, lane A). The degradation of DSF in these experiments is greater than it may appear in Figure 4, since twice as much DSF was added to cell-free extracts before extraction as was added to controls before spotting on the assay plate. The DSF indicator exhibited more total gfp fluorescence in assays of cell-free extracts of a carB mutant of Pseudomonas spp. strain G spiked with DSF than when extracts of strain $G$ itself were spiked (Fig. 4, compare lanes $\mathrm{A}$ and $\mathrm{B}$ ). Extracts of the $c a r B$ mutant that was complemented with $c a r A B$ in trans removed as much DSF as did extracts from parental strain G (Fig. 4, lane D), and the re-

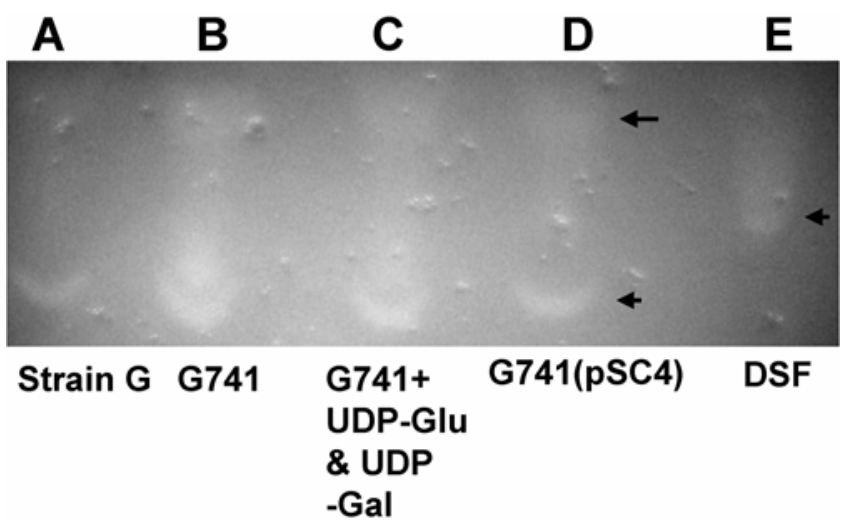

Fig. 4. Modification of diffusible signal factor (DSF) by Pseudomonas spp. strain G. Thin-layer chromatography (TLC) separation of DSF treated with A, cell-free extracts of wild-type Pseudomonas spp. strain G, B, the carB mutant of strain G (G741), C, G741 supplemented with UDP glucose and UDP galactose, D, G741 (pSC4), and E, native DSF extracted from Xanthomonas campestris pv. campestris. DSF was detected by an overlay of $X$. campestris pv. campestris DSF-indicator strain 8523 (pKLN55) on TLC plates. Photograph was taken with the UV light source oriented from the right side of the TLC plate. Similar results were seen in three replicate experiments.
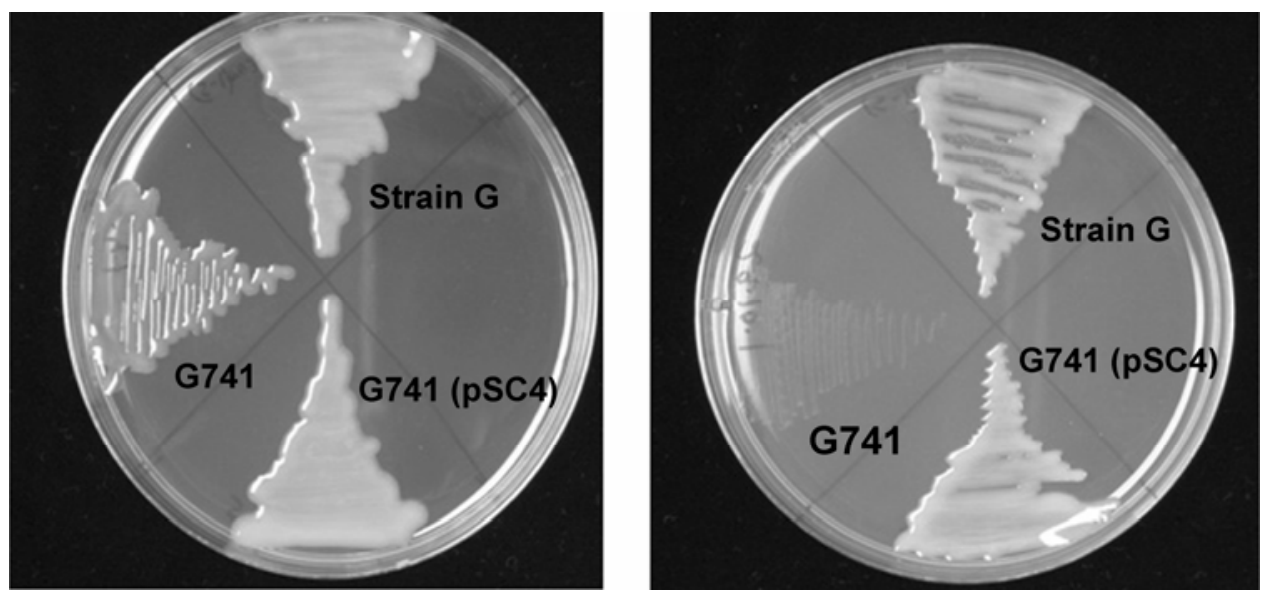

Fig. 3. Diffusible signal factor (DSF) degradation mutants are deficient in exopolysaccharide production in rich King's B (KB) medium. Pseudomonas spp. strain G (wild type), DSF degradation-deficient mutant G741, and strain G741 complemented with pSC4 were grown for 2 days in rich KB medium (left) and M9 minimal medium (right). 
sidual material to which the DSF indicator was responsive was found almost exclusively in the two bands that migrated similarly as when treated with strain G itself (Fig. 4, lane D). Addition of UDP glucose and UDP galactose to the cell-free extracts of the $\operatorname{car} B$ mutant of strain $\mathrm{G}$ slightly reduced the total amount of gfp fluorescence exhibited by the DSF indicator compared with that in extracts of the $\operatorname{car} B$ mutant alone.

\section{Disease control conferred}

\section{by DSF-degrading bacterial strains.}

When coinoculated with $X$. campestris pv. campestris 8004 into mustard and cabbage leaves, all bacterial strains with the high ability to degrade DSF reduced the severity of black rot symptoms compared with plants inoculated with the pathogen alone. While DSF-degrading strains usually conferred more reduction of disease severity when coinoculated with $X$. campestris pv. campestris than did other bacteria, most bacteria conferred some reduction in disease severity (Table 3 ). Such a result might be expected, given the fact that most bacteria, including $E$. coli, have some ability to degrade DSF (Fig. 1). To determine the contribution of carAB-mediated DSF degradation on disease control in mixed bacterial infections, we compared disease severity in mustard and cabbage coinoculated with $X$. campestris pv. campestris and Pseudomonas spp. strain $G$ with that observed in plants coinoculated with the

Table. 3. Reduction in severity of disease on cabbage and turnip plants coinoculated with Xanthomonas campestris pv. campestris and different diffusible signal factor-degrading strains

\begin{tabular}{|c|c|c|}
\hline \multirow[b]{2}{*}{ Strains $^{b}$} & \multicolumn{2}{|c|}{$\begin{array}{l}\text { Seedling lesion length } \\
\left(\mathrm{mm}^{\mathbf{a}}\right)\end{array}$} \\
\hline & Cabbage & Turnip \\
\hline X. campestris pv. campestris (8004) alone & $170 \pm 65$ & $13.8 \pm 2.5$ \\
\hline X. campestris pv. campestris $+\mathrm{C}$ & $48 \pm 10$ & $1.8 \pm 0.5$ \\
\hline$X$. campestris pv. campestris $+\mathrm{G}$ & $30 \pm 5$ & $6.0 \pm 2.7$ \\
\hline X. campestris pv. campestris $+\mathrm{H}$ & $87 \pm 18$ & $1.0 \pm 0.3$ \\
\hline$X$. campestris pv. campestris $+\mathrm{J}$ & $32 \pm 5$ & $1.5 \pm 0.5$ \\
\hline$X$. campestris pv. campestris $+\mathrm{K}$ & $86 \pm 30$ & $1.4 \pm 0.5$ \\
\hline$X$. campestris pv. campestris $+\mathrm{DH} 5 \alpha$ & $45 \pm 8$ & $5.2 \pm 1.2$ \\
\hline
\end{tabular}

a The standard error of the mean is shown.

${ }^{\mathrm{b}}$ Plants were inoculated with $X$. campestris pv. campestris alone or coinoculated with this pathogen and one of the indicated strains in equal concentrations.

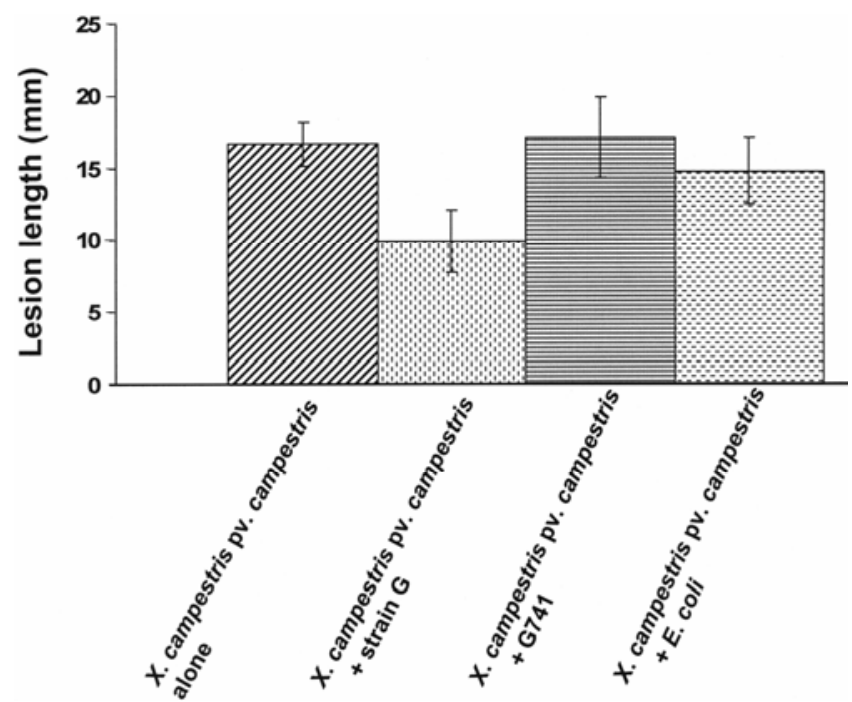

Fig. 5. Severity of disease in mustard seedlings caused by Xanthomonas campestris pv. campestris when coinoculated with Pseudomonas spp. strain $\mathrm{G}$ or with the $\operatorname{car} A B$ mutant G741. Lesion lengths were measured from the point of inoculation. Error bars represent the standard error of the mean. pathogen and the carB mutant G741. Disease severity was always less in plants coinoculated with wild-type strain $G$ than in plants coinoculated with the $c a r B$ mutant (Fig. 5; Table 3). The severity of disease in plants coinoculated with $E$. coli DH5 $\alpha$ was greater than that in plants coinoculated with strain $\mathrm{G}$ but less than that of plants coinoculated with $\operatorname{carB}$ mutant G741 (Fig. 5). It is important to note that the E. coli strain was more efficient in DSF degradation than carB mutant strain G741 but much less efficient than strain G itself (Fig. 1).

To ensure that the reduction in ability of the $c a r B$ mutant to suppress disease when coinoculated with $X$. campestris pv. campestris was not due simply to a deficiency in multiplication at the infection site, we compared its population size with that of strain $\mathrm{G} 24 \mathrm{~h}$ after coinoculation with the pathogen. The population sizes of both the $c a r B$ mutant and strain $G$ had increased within $24 \mathrm{~h}$ after coinoculation with $X$. campestris pv. campestris and did not differ significantly, indicating that plant compounds had enabled the growth of this auxotroph within damaged tissues (data not shown).

The incidence or severity of Pierce's disease of grape was always lower in plants coinoculated with Xylella fastidiosa and DSF-degrading bacterial strains than in grape plants inoculated with the pathogen alone (Figs. 6 and 7). To determine the contribution of $c a r A B$-mediated DSF degradation on disease control in mixed bacterial infections, we compared disease severity in grape coinoculated with Xylella fastidiosa and Pseudomonas spp. strain $G$ with that observed in plants coinoculated with the pathogen and $\operatorname{carB}$ mutant G741. Disease severity was always less in grape coinoculated with Xylella fastidiosa and wild-type Pseudomonas spp. strain $G$ than in plants coinoculated with the $\operatorname{carB}$ mutant (Figs. 6 and 7). Restoration of car $A B$ activity by complementation of the Pseudomonas spp. strain $\mathrm{G}$ carB mutant $\mathrm{G} 741$ rescued the ability of this mutant to reduce Pierce's disease when coinoculated with Xylella fastidiosa into grape (Fig. 7). In some experiments disease was reduced significantly more than that conferred by strain $\mathrm{G}$ when $\operatorname{car} A B$-overexpressing strains were coinoculated with Xylella fastidiosa (data not shown).

\section{DISCUSSION}

$\operatorname{car} A B$ encodes the large and small subunits of carbamoyl phosphate synthetase, which in turn catalyzes the synthesis of carbamoylphosphate, an important precursor of arginine and pyrimidines. It is interesting that not only are $\operatorname{car} A B$ mutants in Pseudomonas spp. strain G auxotrophic for arginine and pyri-

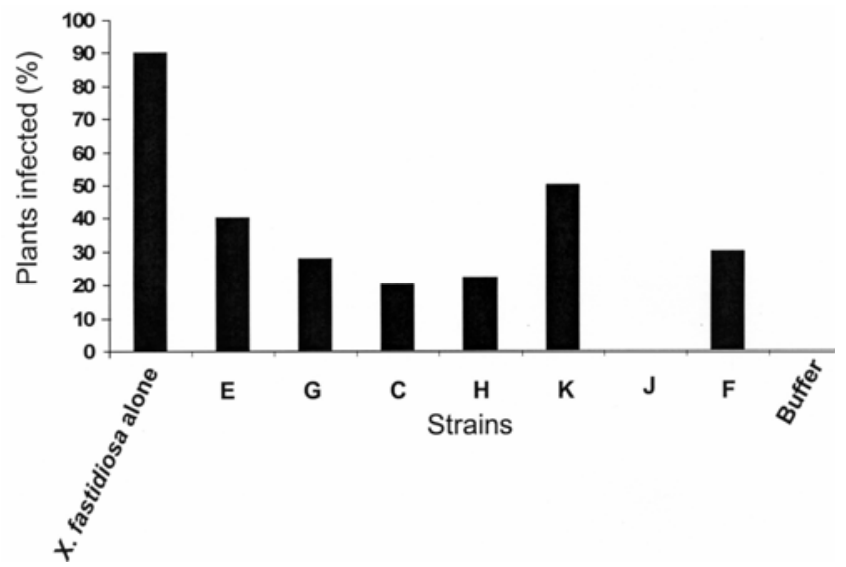

Fig. 6. Incidence of Pierce's disease of grape coinoculated with Xylella fastidiosa Temecula alone or with one of several different diffusible signal factor-degrading bacterial strains. Disease incidence was quantified 112 days after inoculation. 
mydine but they are also deficient in EPS production. Complementation of the $\operatorname{carB}$ mutant G741 with the plasmid pSC4 containing $c a r A B$ restored both prototrophy and EPS production. It has been reported that a $c a r A B$ mutant strain of Halomonas eurihalina is also deficient in EPS production (Llamas et al. 2003). This might be expected if there is a deficiency in the UDP-sugar pool. These compounds are essential to the synthesis of nucleotide di-phospho-sugar precursors such as UDP glucose and UDP galactose. UDP sugar is utilized in the synthesis not only of extracellular polysaccharides but also of lipopolysaccharides and the glycosylation of lipids and fatty acids. To explain the role of carAB in Pseudomonas spp. strain G in the degradation of DSF, we propose that they encode an enzymatically highly active carbamoylphosphate synthetase, which in turn, is responsible for both pyrimidine and arginine biosynthesis and also for high accumulation of UDP-sugar precursors like UDP glucose and UDP galactose. The DSF of $X$. campestris pv. campestris is a fatty acid molecule (Wang et al. 2004). We show here that it is modified to at least two altered forms that are at least weakly detectable by the $X$. campestris pv. campestris DSF biosensor and, presumably, to other forms that are not, since the amount of DSF detectable with the $X$. campestris pv. campestris biosensor is greatly reduced in the presence of strain G (Fig. 4). It is also possible that the modified DSF forms are a suitable substrate for another degrading enzyme or pathway and is being rapidly broken down before it could be sensed by the $X$. campestris pv. campestris biosensor. It has been reported that many bacteria, such as Bacillus subtilis, Staphylococcus aureus, and Pseudomonas aeruginosa, employ UDP-sugar transferases to modify the fatty acid component of lipids (Dotson et al. 1998; Jorasch et al. 1998, 2000). Cellular pools of UDP- $N$-acetylglucosamine, UDP glucose, and UDP galactose are utilized as substrates to add a sugar moiety to the fatty acid component of various lipids. We suggest that the modified forms of DSF detected here reflect such modifications. It is possible that, due to lack of sufficient cellular UDP-sugar levels in the $\operatorname{carB}$ mutant G741, it has reduced ability to modify DSF. While we have not confirmed the structure of these apparent modified forms of DSF, we speculate that they are glycosylated. While a $\operatorname{car} A$ or $\operatorname{car} B$ mutant is blocked in its production of carbamoylphospate, a necessary precursor for pyrimidine and arginine biosynthesis, such mutants can still produce smaller amounts of UDP sugars via the salvage pathway by which intermediates downstream in the pyrimydine biosynthetic pathway can be acquired from the extracellular environment of the bacteria (Neuhard and Kelln 1996). While the salvage pathway does not enable growth of $c a r A B$ mutants in a minimal medium, presumably due to a low rate of pryimidine synthesis, such mutants can grow in rich media in which intermediates such as orotic acid are present (Neuhard and Kelln 1996). Such intermediates would be expected to be present in the rich media, in which the $\operatorname{car} A B \mathrm{mu}-$ tants of strain $\mathrm{G}$ were grown in this study as well as in damaged plant tissues. It might thus be expected that the $\operatorname{car} B$ mutant would exhibit a "leaky" phenotype when compared with strain $\mathrm{G}$ itself for DSF degradation. Indeed, while both strain G and the $c a r B$ mutant were capable of at least some DFS degradation (Fig. 1) and both modified forms of DSF were observed when DSF was exposed to cell-free extracts of both strains (Fig. 4), the $\operatorname{car} B$ mutant was much reduced in both cases. This is likely due to a much lower pool size of UDP sugars present in the $\operatorname{car} B$ mutant as compared with that in strain $G$, although addition of UDP glucose and UDP galactose to cell extracts of the $\operatorname{car} B$ mutant increased DSF degradation only slightly, possibly due to other limiting factors in this strain.

The ability of bacteria to interfere with the disease process was correlated with their ability to interfere with DSF degradation. In our initial screen, we isolated nine bacterial strains that interfered with DSF detection in our plate assay. Pseudomonas spp. strain $G$ was a particularly prominent example of such bacteria and appeared to rapidly degrade DSF. Incubation of DSF with cells or cell extracts of a variety of other bacteria, such as the laboratory strains of E. coli, and other pseudomonads and Erwinia herbicola conferred some DSF degradation (Table 2). This suggests that most bacteria have the intrinsic ability to degrade DSF, although at a much lower rate compared with strains such as Pseudomonas spp. strain G. It is intriguing to note that $E$. coli, which has an intrinsic ability to degrade DSF at a much slower rate than Pseudomonas spp. strain $\mathrm{G}$, also has reduced ability to degrade DSF when its carA is mutated. This indicates that the cellular pool of UDP sugar may also contribute to the modification or degradation of DSF in other laboratory strains and, presumably, most bacteria, which are not efficient degraders of DSF. Ability to degrade DSF in vitro correlated well with the ability to interfere with the disease process in planta for the strains tested. Coinoculation of mustard with $X$. campestris pv. campestris and $E$. coli resulted in more disease than when strain $\mathrm{G}$ was coinoculated with the pathogen but less severe disease than when a $\operatorname{car} B$ mutant was coinoculated (Fig. 4). This ranking of effectiveness of such strains is as we would expect if DSF degradation is the main mechanism of interfering with the disease process, since E. coli degraded DFS more rapidly than the carB mutant of strain $\mathrm{G}$ but much less rapidly than strain $\mathrm{G}$ itself (Fig. 1). The suppression of disease when Xylella fastidiosa was coinoculated into grape xylem with other bacterial strains was dependent on their ability to interfere with DSFmediated signaling. The severity of disease in grape coinoculated with a $\operatorname{carB}$ mutant of Pseudomonas spp. strain G was much greater than when inoculated with the wild-type strain (Figs. 6 and 7). Furthermore, overexpression of $\operatorname{car} A B$ in strain G741 conferred greater ability to reduce disease when coinoculated with Xylella fastidiosa than the parental strain G (Fig. 7) and, in some experiments, provided even better disease control than the parental strain $\mathrm{G}$.

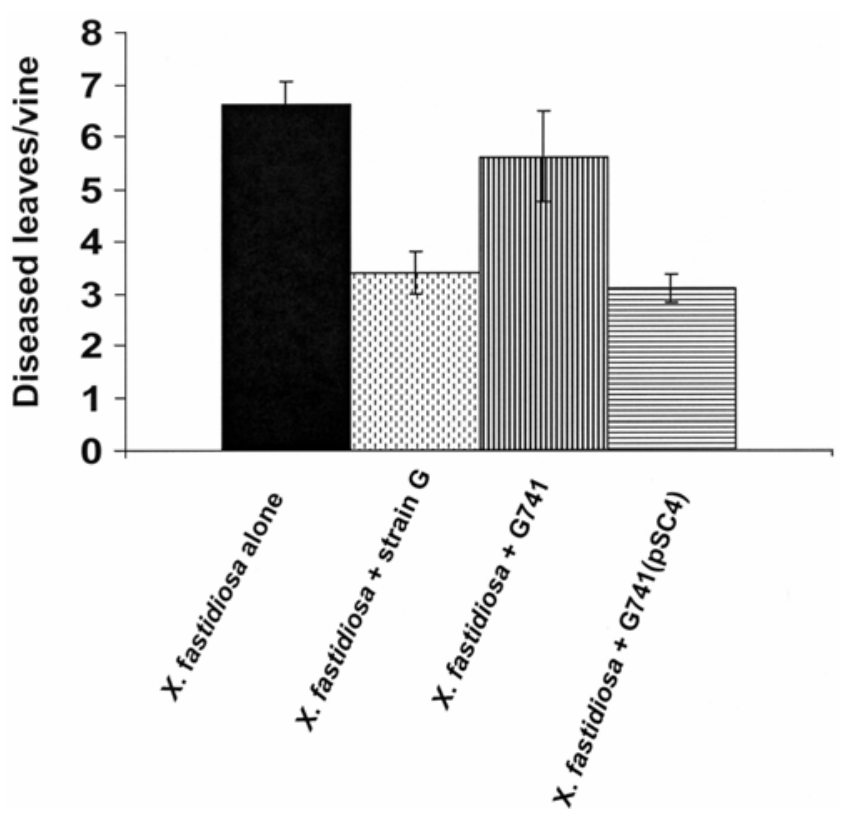

Fig. 7. Severity of Pierce's disease of grape coinoculated with Xylella fastidiosa STL and diffusible signal factor-degrading Pseudomonas spp. strain G, CarAB mutant G741 of Pseudomonas spp. strain G, or with mutant G741 complemented with pSC4, as measured 3 months after inoculation. The vertical bars represent the standard error of the mean of the number of symptomatic leaves per vine. 
It is somewhat surprising that disruption of DSF-mediated signaling suppressed the virulence of Xylella fastidiosa to grape. Given that DSF-deficient mutants of Xylella fastidiosa are hypervirulent to grape, DSF is apparently involved in regulating traits that overall lead to a reduction of virulence in this pathogen. It is reasonable to presume, based on studies of AHLmediated control of virulence in other bacterial species (Cui and Harling 2005; Mäe et al. 2001; vonBodman et al. 2003; Zhang 2003), that DSF production and regulation of virulence traits by DSF itself is also governed by fine tuning of DSF production during growth of the pathogen inside the plant host. Therefore degradation of DSF might create an imbalance of DSF levels at particular stages of invasion of the plant that would tend to reduce the success of this pathogen in movement within plants or expression of other traits that would lead to symptom development. Clearly a better understanding of the process of infection of grape with Xylella fastidiosa is needed to explain how DSF signal disruption can lead to reduced disease.

Given that DSF production is required for virulence in xanthomonads such as $X$. campestris pv. campestris and $X$. oryzae pv. oryzae (Barber et al. 1997; Chatterjee and Sonti 2002), the finding that coinoculation of DSF-degrading bacterial strains with $X$. campestris pv. campestris conferred reduction in disease severity (Fig. 5) is most likely due to the reduction of this needed cell-to-cell signaling factor at the site of infection. It might be expected that other interactions between this pathogen and interfering strains, such as competition for limited resources, also could contribute to reduced disease in coinoculated plants compared with plants inoculated only with the pathogen (Wilson and Lindow 1993, 1994). Importantly, we found that disease severity in mustard coinoculated with $X$. campestris pv. campestris and a carB mutant of Pseudomonas spp. strain $G$ was similar to that of plants inoculated only with the pathogen and was much higher than that of plants coinoculated with parental strain $G$ (Fig. 5). Our finding that the auxotrophic $c a r B$ mutant grew equally well in the wounded plant tissue as the parental strain $G$ indicated that sufficient pyrimidines are present in the plant to enable normal growth of the mutant and that its deficiency in disease suppression is not simply due to its lack of growth at the infection site. It is interesting to note that a folate auxotrophic mutant of Ralstonia solanacerum that exhibited deficiency in growth in leaf intercellular spaces grew like the wild type in the xylem sap (Shinohara et al. 2005), suggesting that such plant metabolites are sufficiently abundant in the plant, especially in the xylem, in which infection by $X$. campestris pv. campestris is initiated. It thus appears that DSF signal disruption was a far more important mechanism of interactions than competition in these infections.

Pathogen confusion has recently been recognized as a potential new strategy for disease control (Cui and Harling 2005; Gonzalez and Keshavan 2006; Zhang 2003). This phenomenon has been addressed exclusively in bacterial pathogens that produce AHL signal molecules and has largely been restricted to tests in the laboratory of model systems in which bacterial producers and degraders of AHL have been assessed for their ability to alter the disease process (Cui and Harling 2005). Likewise a few studies have shown that production of and degradation of AHL signals in transgenic plants producing AHL synthases and lactonases exhibit altered disease susceptibility (Dong et al. 2001). This study extends the concept of pathogen confusion to the large group of plant pathogens that regulate virulence via production of DSF-like molecules. Our results show that strains capable of DSF degradation or modification can be readily identified by the screening method that we have developed. Furthermore, it appears that the activity of many of these strains is due to a $\operatorname{car} A B$ dependent mechanism that can be manipulated. Thus, not only do naturally occurring strains such as Pseudomonas spp. strain $\mathrm{G}$ appear promising as biocontrol agents for diseases caused by X. campestris pv. campestris, Xylella fastidiosa, and other xanthomonads, our results suggest that it should be possible to make superior strains by selecting for enhanced CarAB activity in naturally occurring or transgenic strains. Further work is underway to test such strains under various settings and to devise methods to best enable them to interact with these pathogens in a way that will lead to disease suppression.

\section{MATERIALS AND METHODS}

\section{Identification of bacterial strains interfering with DSF-mediated signaling.}

Bacteria were isolated from macerates of tomato leaves with symptoms of bacterial spot caused by Xanthomonas campestris pv. vesicatoria, from cabbage and broccoli leaves with black rot symptoms caused by $X$. campestris pv. campestris, and from stems of symptomatic and asymptomatic grape (cv. Cabernet). Plant material was macerated with a mortar and pestle in $10 \mathrm{mM} \mathrm{KPO}_{4}$ buffer and appropriate dilutions plated on $10 \%$ trypticase soy agar (Difco, Detroit). Plates were incubated at $28^{\circ} \mathrm{C}$ for 4 days, and single colonies representing the diversity of bacteria on a given plate were spotted onto fresh plates and oversprayed with a suspension of the DSF biosensor strain X. campestris pv. campestris 8004 (pKLN55). This strain, was constructed by mating pKLN55 harboring the DSFinducible eng:gfp reporter gene fusion (Newman et al. 2004) into $X$. campestris pv. campestris wild-type strain 8004 (Turner et al.1984), which produces its own DSF. When its DSF is degraded by a neighboring strain or one that somehow blocks the perception of DSF by strain 8004, its GFP fluorescence is decreased. Assay plates were viewed under blue light as previously described (Newman et al. 2004). The identity of bacterial strains was determined by partial sequence analysis of cloned 16S ribosomal RNA genes. PCR amplification of DNA from colonies of strains grown on $\mathrm{KB}$ was performed using 16S F: 5'-GGAGAGTTAGATCTTGGCTCAG-3' and 16S R: 5'-GTGCTGCAGGGTTACCTTGTTACGACT-3' primers similar to other studies. Cycling conditions were as follows: $95^{\circ} \mathrm{C}$ for $3 \mathrm{~min}$ for initial denaturation. 32 cycles of $94^{\circ} \mathrm{C}$ for $30 \mathrm{~min}, 54^{\circ} \mathrm{C}$ for $30 \mathrm{~min}$, and $72^{\circ} \mathrm{C}$ for $1 \mathrm{~min}$. Tentative phylogenic placement of strains was made using comparisons to the ribosomal DNA sequence using BLAST search with the NCBI GenBank database (Altschul et al. 1997).

\section{Construction of DSF degradation-deficient mutants.}

Tn5-mutants of Pseudomonas spp. strain G were produced by introduction of the suicide plasmid pRL27 from E. coli by conjugation as described before (Larsen et al. 2002). Transposon mutants were selected on $\mathrm{KB}$ containing $15 \mu \mathrm{g}$ of kanamycin per milliliter. A total of 11,300 colonies from 20 independent matings were screened by spotting colonies onto KB plates and overspraying them with the $X$. campestris pv. campestris DSF biosensor 8004 (pKLN55) as described above. Colonies that failed to produce a halo of nonfluorescent biosensor cells were subjected to a secondary screen on $20 \%$ trypticase soy agar plates. To ascertain whether putative mutants were unable to degrade DSF, a DSF degradation assay was performed as described below, using cultures of the putative mutant strains. The 16S ribosomal RNA gene from each mutant was sequenced as above to confirm that they were indeed derivatives of strain G. To determine the sequence of the Tn5 insertion site, BamHI-digested, circularized genomic DNA from each mutant was electroporated into $E$. coli $\mathrm{DH} 5 \alpha \lambda$ pir cells. Plasmids re- 
covered from two independent transformants from each mutant were sequenced with primers tpnRL 17-1 and tpnRL 13-2 (Larsen et al. 2002), oriented outward from the transposon flanks. Tn5 inverted repeats were flanked by a 9-bp duplication of the target sequence, TCGAAGACC, as expected at Tn5 insertion sites.

\section{DSF degradation assays.}

DSF degradation was detected in either live cultures or their protein extracts as follows. Strains were inoculated into $5 \mathrm{ml}$ of $20 \%$ tryticase soy broth and were incubated at $28^{\circ} \mathrm{C}$ with shaking overnight. An amount of X. campestris pv. campestris 8004 culture extract (DSF source) corresponding to $5 \mathrm{ml}$ of culture (with an optical density at $600 \mathrm{~nm}\left(\mathrm{OD}_{600}\right)=1.0$ ) was added to a cell suspension or crude protein extract of a test culture and was incubated at $28^{\circ} \mathrm{C}$ overnight. Cells, when present, were removed by centrifugation $(14,000 \times g$ for $10 \mathrm{~min})$ and any remaining DSF was extracted from the supernatant with ethyl acetate and was detected using the DSF biosensor $X$. campestris pv. campestris 8523 (pKLN55 [which does not produce any DSF]) as described by Newman and associates (2004). Proteins were extracted from cultures using the Easy-Lyse bacterial protein extraction kit (Epicenter, Madison, WI, U.S.A.).

To estimate the amount of DSF in samples, a standard curve reflecting the area of detectable gfp fluorescence surrounding wells in agar plates to which known amounts of DSF were added was prepared. DSF was extracted from an overnight culture of X. campestris pv. campestris 8004 (150 ml in KB media) by partitioning the culture supernatant with an equal volume of water-saturated ethyl acetate. After evaporating the extract to dryness in a rotary evaporator, it was dissolved in 1 $\mathrm{ml}$ of methanol. Different amounts of this standard source of DSF (from 0 to $60 \mu \mathrm{l}$ ) was added to $\mathrm{KB}$ broth and mixed by vortexing. DSF units are given as volume of DSF (in $\mu$ l) added to $\mathrm{KB}$ broth before extraction by ethyl acetate. DSF was then extracted with an equal volume of ethyl acetate, dried under vacuum, and resuspended in $60 \mu \mathrm{l}$ of methanol. The extracted DSF was placed on a disk of sterile filter paper (Whatman no. 3; $0.7 \mathrm{~mm}$ diameter) placed on the surface of a KB plate, and a suspension of the GFP indicator $X$. campestris pv. campestris 8523 (pKLN55) was applied perpendicular to the disk on the indicator plate, as described by Newman and associates (2004). The radial distance from the center of the filter disk to the distal edge of visible gfp fluorescence in the indicator strain was measured after incubation for $42 \mathrm{~h}$ at $28^{\circ} \mathrm{C}$, and the square of the zone area was plotted against DSF concentration (expressed as arbitrary DSF units). Rates of DSF degradation were measured by adding $50 \mu \mathrm{l}$ of DSF from $X$. campestris pv. campestris to $3 \mathrm{ml}$ of cell suspension of test strains, and DSF was subsequently extracted and quantified after various incubation times as above.

\section{Cloning of $\operatorname{car} A B$ genes from strain $\mathrm{G}$.}

Primers CarA F1 BamHI-GGGATCCGTGGTAGAC CAAA ATGGG CCTTTTC TGTAAGC and CarB R1 BamHI-GGGA TCCCAT GCCTTCAA TCCTGC ATG GAGGTCCTGC were used to amplify the $c a r A B$ operon, along with $140 \mathrm{bp} 5^{\prime}$ from this locus in samples of genomic DNA of Pseudomonas spp. strain G. PCR was carried out with Expand long high-fidelity Taq polymerase (Roche Applied Science, Indianapolis, IN, U.S.A.) according to the manufacturer's instructions. The PCR product was then A-tailed with Taq DNA polymerase (Clontech, Palo Alto, CA, U.S.A.) and cloned into the TA-cloning vector PCR2.1 (Clontech). The clones obtained were confirmed by sequencing and were digested with Bam HI to release the insert. The insert was then cloned into the stable, broad-host range vector pVSP61 (Whalen et al. 1991) to generate clone pSC4.
pSC4 was transferred to the Tn5 mutants G741, G29101, G2951, and E. coli strains by electroporation at 200 ohms, 2.1 $\mathrm{kV}$, using a BioRad electroporator (BioRad, Hercules, CA, U.S.A.). All molecular biology techniques were done according to Sambrook and associates (1989).

\section{Separation and detection of DSF on TLC plates.}

DSF extracted from $X$. campestris pv. campestris 8004 was incubated with the cell-free extracts of different strains as described above. Briefly, $1 \mathrm{ml}$ of cell-free extract (the equivalent of protein extracted from $10^{9}$ cells) was mixed with $2 \mathrm{ml}$ of 10 $\mathrm{mM}$ Tris-Cl buffer ( $\mathrm{pH} 7.5$ ). DSF was then added to the mixture. For UDP-sugar supplementation, UDP glucose and UDP galactose was added to a final concentration of $60 \mathrm{mM}$. The reaction mixture was incubated for $1 \mathrm{~h}$. The DSF remaining in the reaction mixture was then extracted with ethyl acetate as described above and, finally, dissolved in methanol. Only half the amount of DSF from the native $X$. campestris pv. campestris strain as that used for the DSF-degrading strains was spotted onto TLC assay plates to enable better visualization of neighboring lanes due to the spreading of the DSF spot. The native $X$. campestris pv. campestris DSF was spotted half the equivalent amount used for the DSF degrading strains for better visualization of neighboring lanes in the TLC. The extracted DSF was spotted on C-18 reverse-phase silica TLC plates ( $\mathrm{J}$. T. Baker, Phillipsburg, NJ, U.S.A.), and DSF on the plates was resolved with $70 \%$ methanol. The plates were later dried and overlayed with a thin layer of $0.7 \% \mathrm{~KB}$ agar containing $10^{8}$ cells of the $X$. campestris pv. campestris DSF indicator strain 8523 (pKLN55) per milliliter. The plates were then also sprayed with a suspension of the indicator strain as above. Plates were incubated at $28^{\circ} \mathrm{C}$ for $48 \mathrm{~h}$ and GFP fluorescence was visualized under UV illumination.

\section{Plant inoculations.}

Mustard (Brassica juncea), cabbage (B. oleracea var. capitata), and turnip (B. rapa; White turnip Hakurei Hybrid) were inoculated by clipping the three youngest leaves of six plants per treatment with scissors dipped in a solution of bacteria in $10 \mathrm{mM} \mathrm{KPO}{ }_{4}$ buffer $\left(\mathrm{OD}_{600}=0.1\right)$, as described previously (Castañeda et al. 2005; Dow et al. 2003), and then incubating them in a greenhouse for 10 to 14 days. Lesion length along the midrib was measured. Grapevines (cv. Cabernet Sauvignon) were grown from rooted green or dormant cuttings to a height of about $40 \mathrm{~cm}$ in a greenhouse. A 5 - $\mu 1$ drop of a suspension of bacterial cells (approximately $10^{9} \mathrm{CFU} / \mathrm{ml}$ ) was pipetted onto the stem of a grapevine and was pierced using an insect-mounting needle, enabling the suspension to be quickly drawn into the xylem as previously described (Hill and Purcell 1995). In all cases, when a mixture of bacterial strains was inoculated, strain mixing occurred immediately prior to inoculation. Equal concentrations of an antagonistic strain were mixed with $X y$ lella fastidiosa Temecula or STL. Plants were subsequently grown in a greenhouse with maximum daytime temperatures ranging from 28 to $36^{\circ} \mathrm{C}$ and supplemental lighting to ensure at least $16 \mathrm{~h}$ of light per day. Symptoms were quantified weekly for up to 16 weeks.

\section{ACKNOWLEDGMENTS}

We thank R. Hoenisch, S. Koike, the Olivier Vineyard, the Krug Vineyard, the Robert Mondavi Vineyard, and T. Momol for plant material, and R. Koutsoukis, S. M. Lo, D. Okamoto, and S. Rashby for technical assistance. We are grateful to M. Dow and D. Dahlbeck for strains and advice. This material is based upon work supported by the National Science Foundation under a grant awarded to K. L. Newman in 2002 and by funding from the American Vineyard Foundation, the California Competitive Grant Program for Research in Viticulture and Enology, and the California De- 
partment of Food and Agriculture, Pierces Disease and Glassy-winged Sharpshooter Research Board.

\section{LITERATURE CITED}

Altschul, S. F., Madden, T. L., Schaffer, A. A., Zhang, J., Zhang, Z., Miller W., and Lipman, D. J. 1997. Gapped BLAST and PSI-BLAST: A new generation of protein database search programs. Nucleic Acids Res. 25:3389-3402.

Barber, C. E., Tang, J. L.., Feng, J. X., Pan, M. Q., Wilson, T. J. G., Slater, H., Dow, J. M., Williams, P., and Daniels, M. J. 1997. A novel regulatory system required for pathogenicity of Xanthomonas campestris is mediated by a small diffusible signal molecule. Mol. Microbiol. 24:555-566.

Bassler, B. L. 2002. Small talk: Cell-to-cell communication in bacteria. Cell 109:421-424.

Belien, T., Van Campenhout, S., Robben, J., and Volckaert, G. 2006. Microbial endoxylanases: Effective weapons to breach the plant cell-wall barrier or, rather, triggers of plant defense systems? Mol. Plant-Microbe Interact. 19:1072-1081.

Buell, C. R., et al. 2003. The complete genome sequence of Arabidopsis and tomato pathogen Pseudomonas syringae pv. tomato DC3000. Proc. Natl. Acad. Sci. U.S.A. 100:10181-10186.

Castañeda, A., Reddy, J. D., El-Yacoubi, B., Gabriel, D. W. 2005. Mutagenesis of all eight avr genes in Xanthomonas campestris pv. campestris had no detected effect on pathogenicity, but one avr gene affected race specificity. Mol. Plant-Microbe Interact. 18:1306-1317.

Chatterjee, S., and Sonti, R. V. 2002. rpfF mutants of Xanthomonas oryzae pv. oryzae are deficient for virulence and growth under low iron conditions. Mol. Plant-Microbe Interact. 15:463-71.

Cho, H. S., Park, S. Y., Ryu, C. M., Kim, J. F., Kim, J. G., and Park, S. H. 2007. Interference of quorum sensing and virulence of the rice pathogen Burkholderia glumae by an engineered endophytic bacterium. FEMS (Fed. Eur. Microbiol. Soc.) Microbiol. Ecol. 60:14-23.

Colnaghi, S. A. V., da Silva, D. S., Lambais, M. R., and Carrilho, E. 2007 Characterization of a putative Xylella fastidiosa diffusible signal factor by HRGC-EI-MS. J. Mass Spectrom. 42:490-496.

Cui, X., and Harling, R. 2005. $N$-acyl-homoserine lactone-mediated quorum sensing blockage, a novel strategy for attenuating pathogenicity of gramnegative bacterial plant pathogens. Eur. J. Plant Pathol. 111:327-339.

Dong, Y. H., and Zhang, L. H. 2005. Quorum sensing and quorum-quenching enzymes. J. Microbiol. 43:101-109.

Dong, Y. H.., Xu, J. L., Li, X. Z., and Zhang, L. H. 2000. AiiA, an enzyme that inactivates the acylhomoserine lactone quorum-sensing signal and attenuates the virulence of Erwinia carotovora. Proc. Natl. Acad. Sci. U.S.A. 97:3526-31.

Dong, Y. H., and Wang, L. H., Xu, J. L., Zhang, H. B., Zhang, X. F., and Zhang, L. H. 2001. Quenching quorum-sensing-dependent bacterial infection by an $N$-acyl homoserine lactonase. Nature 411:813-7.

Dotson, G. D., Kaltashov, I. A., Cotter, R. J., and Raetz, C. R. H.1998. Expression cloning of a Pseudomonas gene encoding a hydroxydecanoylacyl carrier protein-dependent UDP-GlcNAc acyltransferase. J. Bacteriol. 180:330-337.

Dow, J. M., L. Crossman, K. Findlay, Y. Q. He, J. X. Feng, and J. L. Tang. 2003. Biofilm dispersal in Xanthomonas campestris is controlled by cell-cell signaling and is required for full virulence to plants. Proc. Natl. Acad. Sci. U.S.A. 100:10995-11000.

Feil, H., Feil, W. S., Chain, P., Larimaer, F., DiBartolo, G., Copeland, A., Lykidis, A., Trong, S., Nolan, M., Goltsman, E., Thiel, J., Malfatti, S., Loper, J. E., Lapidus, A., Detter, J.C., Land, M., Richardsson, P. M., Kyrpides, N. C., Ivanova, N., and Lindow, S. E. 2005. Comparision of the complete genome sequence of Pseudomonas syringae pv. syringae B728a and pv. tomato DC3000. Proc. Natl. Acad. Sci. U.S.A. 102:11064-11069.

Gonzalez, J. E., and Keshavan, N. D. 2006. Messing with bacterial quorum sensing. Microbiol. Mol. Biol. Rev. 70:859-875.

Hill, B. L., and Purcell, A. H. 1995. Multiplication and movement of Xylella fastidiosa within grapevine and four other plants. Phytopathology 85:1368-1372.

Jha, G., Rajeshwari, R., and Sonti, R. V. 2005. Bacterial type two secretion system secreted proteins: Double-edged swords for plant pathogens. Mol. Plant-Microbe Interact. 18:891-898.

Jorasch, P., Wolter, F. P., Zähringer, U., and Heinz, E. 1998. A UDP glucosyltransferase from Bacillus subtilis successively transfers up to four glucose residues to 1,2-diacylglycerol: Expression of ypfP in Escherichia coli and structural analysis of its reaction products. Mol. Microbiol. 29:419-430.

Jorasch, P., Warnecke, D. C., Lindner, B., Zähringer, U., and Heinz, E. 2000. Novel processive and nonprocessive glycosyltransferases from Staphylococcus aureus and Arabidopsis thaliana synthesize glycoglycer- olipid, glycophospholipid, glycosphingolipis and glycosylsterols. Eur. J. Biochem. 267:3770-3783.

Kievit, T. R., and Iglewski, B. H. 2000. Bacterial quorum sensing in pathogenic relationship. Infection and Immunity 68:4839-4849.

King, E. O., Ward, M. K., and Raney, D. E. 1954. Two simple media for the demonstration of pyocyanin and fluorescein. J. Lab. Clin. Med. 44:310 307.

Kwon, D.-H., Lu, C.-D., Walthall, D. A., Brown, T. M., Houghton, J. E., and Abdelal, A. T. 1994. Structure and regulation of $\operatorname{car} A B$ operon in Pseudomonas aeruginosa and Pseudomonas stutzeri: No untranslated region exists. J. Bacteriol. 176:2532-2547.

Larsen, R. A., Wilson, M. M., Guss, A. M., and Metcalf, W. W. 2002. Genetic analysis of pigment biosynthesis in Xanthomonas autotrophicus Py2 using a new, highly efficient transposon mutagenesis system that is functional in a wide variety of bacteria. Arch. Microbiol. 178:193-201.

Llamas, I., Suárez, A., Quesada, E., Bějar, V., and Moral, A.D. 2003. Identification and characterization of $\operatorname{car} A B$ genes responsible for encoding carbamoylphosphate synthetase in Halomonas eurihalina. Extremophiles 7:205-211

Mäe, A., Montesano, M., Koiv., V., and Palva, E. T. 2001. Transgenic plants producing the bacterial pheromone $N$-acyl-homoserine lactone exhibit enhanced resistance to the bacterial phytopathogen Erwinia carotovora. Mol. Plant-Microbe Interact. 14:1035-1042.

Mergeay, M. D, Beckmann, G. J, Glansdorff, N., and Piěrard, A. 1974. Physiology and genetics of carbamoyl-phosphate synthesis in Escherichia coli K 12. Mol. Gen. Genet. 133:299-316.

Neuhard, J., and Kelln, R. A. 1996. Biosynthesis and conversions of pyrimidines. Pages 580-599 in: Escherichia coli and Salmonella: Cellular and Molecular Biology. F. C. Neidhardt, R. Curtiss, III, J. L Ingraham., E. C. C. Lin, K. B. Low, B. Magasanik, W. S. Reznikoff, M. Riley, M. Schaechter, and H. E. Umbarger, eds. American Society for Microbiology, Washington, D.C.

Newman, K. L., Almeida, R. P. P., Purcell, A. H., and Lindow, S. E. 2004. Cell-cell signaling controls Xylella fastidiosa interactions with both insects and plants. Proc. Natl. Acad. Sci. U.S.A. 101:1737-1742.

Paulsen, I. T., Press, C. M., Ravel, J., Kobayashi, D. Y., Myers, G. S. A., Mavrodi, D. V., DeBoy, R. T., Seshadri, R., Ren, Q. H., Madupu, R., Dodson, R. J., Durkin, A. S., Brinkac, L. M., Dugherty, S. C., Sullivan, S. A., Rosovitz, M. J. Gwinn, M. L., Zhou, L. W., Schneider, D. J., Cartinhour, S. W., Nelson, W. C., Weidman, J., Watkins, K., Tran, K., Khouri, H., Pierson, E. A., Pierson, L. S., Thomashow, L. S., and Loper, J. E. 2005. Complete genome sequence of plant commensal Pseudomonas fluorescens Pf-5. Nature Biotechnol. 23:873-878

Quiñones, B., Dulla, G., and Lindow, S. E. 2005. Quorum sensing regulates exopolysaccharide production, motility, and virulence in Pseudomonas syringae. Mol. Plant-Microbe Interact. 18:682-693.

Sambrook, J., Fritsch, E. F., and Maniatis, T.A. 1989. Molecular Cloning: A Laboratory Manual. 2nd ed. Cold Spring Harbor Laboratory Press, Cold Spring Harbor, NY, U.S.A.

Scarpari, L. M., Lambais, M. R ., Silva, D. S., Carraro, D. M., and Carrer, H. 2003. Expression of putative pathogenicity-related genes in Xylella fastidiosa grown at low and high cell density conditions in vitro. FEMS (Fed. Eur. Microbiol. Soc.) Microbiol. Lett. 222:83-92.

Shinohara, R., Kanda, A., Ohnishi, K., Kiba, A., and Hikichi, Y. 2005. Contribution of folate biosynthesis to Ralstonia solanacearum proliferation in intercellular spaces. Appl. Environ. Microbiol. 71:417-422.

Turner, P., Barber, C. E., and Daniels, M. J.1984. Behavior of the transposons Tn-5 and Tn-7 in Xanthomonas campestris pathovar campestris. Mol. Gen. Genet. 195:101-107.

von Bodman, S. B., Bauer, W. D., and Coplin, D. L. 2003. Quorum sensing in plant-pathogenic bacteria. Annu. Rev. Phytopathol. 41:455-482.

Wang, L. H., He, Y., Gao, Y., Wu, J. E., Dong, Y. H., He, C., Wang, S. X., Weng, L. X., Xu, J. L., Tay, L., Fang, R. X., and Zhang, L. H. 2004. A bacterial cell-cell communication signal with cross-kingdom structural analogues. Mol. Microbiol. 51:903-912.

Whalen, M. C., Innes, R. W., Bent, A. F., and Staskawicz, B. J. 1991. Identification of Pseudomonas syringae pathogens of Arabidopsis and a bacterial locus determining avirulence on both Arabidopsis and soybean. Plant Cell 3:49-59.

Whitehead, N. A., Barnard A. M., Slater, H., Simpson, J. L., and Salmond, G. P. 2001. Quorum-sensing in Gram-negative bacteria. FEMS Microbiol. Rev. 25:365-404.

Wilson, M., and Lindow, S. E. 1993. Interactions between the biological control agent Pseudomonas fluorescens A506 and Erwinia amylovora in pear blossoms. Phytopathology 83:117-123.

Wilson, M., and Lindow, S. E. 1994. Coexistence among epiphytic bacterial populations mediated through nutritional resource partitioning. Appl. Environ. Microbiol. 60:4468-4477.

Zhang, L. H. 2003. Quorum quenching and proactive host defense. Trends Plant Sci. $8: 238-44$. 